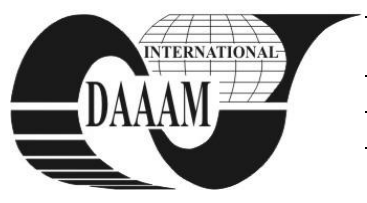

Annals of DAAAM for 2011 \& Proceedings of the 22nd International DAAAM Symposium, Volume 22, No. 1, ISSN 1726-9679 ISBN 978-3-901509-83-4, Editor B. Katalinic, Published by DAAAM International, Vienna, Austria, EU, 2011 Make Harmony between Technology and Nature, and Your Mind will Fly Free as a Bird Annals \& Proceedings of DAAAM International 2011

\title{
THERMAL MANIKINS AS EFFECTIVE TOOLS FOR ASSESSMENT OF THERMAL COMFORT
}

\author{
ZAVEC PAVLINIC, D[aniela]; BALIC, J[oze] \& MEKJAVIC, I[gor]
}

\begin{abstract}
Sweating thermal manikins represent the anatomical shape of the human body, and are used to assess heat exchange between the clothing microenvironment and surrounding ambient. In the field of textiles they are commonly used to evaluate the thermal and evaporative resistances of clothing ensembles, while in the automotive and construction industries they are used for the evaluation of the efficiency of environmental control systems for vehicles, living and working environments. The present study reports the use of a whole body thermal manikin in the process of optimization of existing combat ensembles of the Slovene Armed Forces. Results obtained during field trials conducted with human subjects are compared to results obtained with a thermal manikin.

Key words: thermal manikin, thermal comfort, combat clothing, thermal insulation
\end{abstract}

\section{INTRODUCTION}

Personal protective equipment must allow optimal heat exchange between the wearer and the environment, and should not impair activity, particularly in extreme environmental circumstances (Goldman\&Kampmann, 2007; Umbach, 1987; Zavec Pavlinic\&Mekjavic, 2009). Under normal conditions, thermal and ergonomic comfort (freedom of movement, level of load) is of primary importance, but under extreme environmental conditions, prevention of injuries may become the principal objective. Work in hot and cold environments can result in thermal discomfort, which may impair performance. Exposure to a hot environment may also lead to heat strain, whereas excessive cooling during work in cold environments may cause excessive loss of body heat, resulting in decrements in body core temperature (hypothermia). Maintenance of optimal performance in extreme environmental conditions is therefore achieved by preventing excessive displacements of core temperature. In addition to changes in body heat storage, exposure to extreme thermal environments may also cause regional thermal injury, such as burns, freezing cold (FCI) and non-freezing cold (NFCI) injuries (Mekjavic et al., 2005). Thus, in any given environment, thermal balance will be a function of the activity and heat loss, the latter being defined by the characteristics of the protective clothing ensemble. Army personnel deployed in areas of extreme environmental conditions normally have at their disposal an assortment of clothing items, which they can incorporate in their protective clothing ensemble. Ideally, those responsible for recommending combinations of clothing items for a given activityenvironment scenario would benefit from a table prescribing, or a mathematical model predicting clothing ensembles for such scenarios.

The aim of the present study was to determine the optimal Winter and Summer clothing ensembles for the Slovene Armed Forces. This was achieved by determining the thermal resistance of several clothing ensembles with a thermal manikin, and comparing the results obtained from field trials.

\section{METHODOLOGY}

The study comprised two parts: laboratory trials with a thermal manikin, and field trials with human subjects.

\subsection{Field study}

Trials with human subjects were performed during the winter months in the Julian Alps, and at the Adriatic Coast (Ankaran, Slovenia) during the summer months. The elevation profiles for the $12 \mathrm{~km}$ hiking trails are shown in Figure 1 . During the winter trials in the Julian Alpsthe subjects participated in two trials. In one they performed a 3-hour guard duty, and in the other a 3-hour hike comprising three stages, each consisting of a 50-min walk and a 10-min rest period. In all trials we measured subjects' skin temperature (6 sites), heat flux (6 sites), gastric temperature, forearm-fingertip and calftoe skin temperature gradients, heart rate, ventilation, and oxygen uptake. Ambient temperature, relative humidity, radiant temperature, and wind speed were monitored continuously during the hike and guard duty, albeit only in one location.

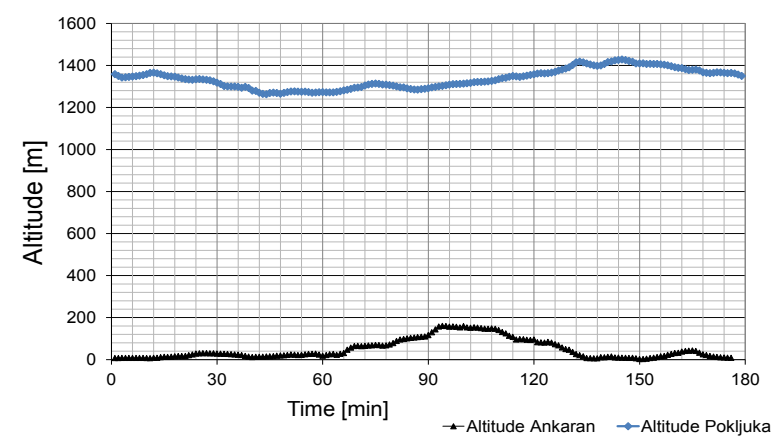

Fig. 1. Altitude profiles of the winter hike at Pokljuka, and the summer hike in Ankaran.

\subsection{Manikin tests}

Thermal resistance (Rt) of the several candidate winter and summer clothing ensembles was determined with a thermal manikin. The surface areas of the manikin regions were: $\operatorname{arm}=$ $0,36 \mathrm{~m}^{2}$; chest $=0,42 \mathrm{~m}^{2} ;$ back $=0,42 \mathrm{~m}^{2} ;$ thigh $=0,56 \mathrm{~m}^{2}$. During the tests thermal flux was measured while the manikin surface temperature was maintained at $35^{\circ} \mathrm{C}$ and the ambient temperature in the climatic chamber at $15^{\circ} \mathrm{C}$. These conditions ensured that the thermal flux was greater than $20 \mathrm{~W} / \mathrm{m}^{2}$ during the assessment of thermal resistance. The thermal resistance for sensible heat transfer from the skin to the ambient is often measured in nearly still air and an empirically derived correlation is then used to account for the effect of wind and motion (Havenith et al., 2004; Qian et al. 2006). The regional thermal insulation, Rt, of the garment in physiological unit - clo $\left(1 \mathrm{clo}=0.155 \mathrm{~m}^{2} \mathrm{~K} / \mathrm{W}\right)$ is computed as follows:

$$
I_{i}=\frac{A_{i}\left(T_{s, i}-T_{a m b}\right)}{0.155 Q_{i}}
$$


where, $\mathrm{A}_{\mathrm{i}}=$ surface of the particular manikin element; $\mathrm{T}_{\mathrm{s}, \mathrm{i}}$ =surface temperature of element $\mathrm{i}\left({ }^{\circ} \mathrm{C}\right) ; \mathrm{T}_{\mathrm{amb}}=\mathrm{ambient}$ temperature $\left({ }^{\circ} \mathrm{C}\right) ; \mathrm{Q}_{\mathrm{i}}=$ rate of heat transfer from element $i$ (Watts).

\section{RESULTS AND DISCUSSION}

Tested protective clothing ensembles worn during field trials were somewhat different from those evaluated using thermal manikin, because soldiers wore a backpack and carried an instrument package on the chest, and those elements were not part of the ensemble tested in the laboratory. Combat clothing ensembles enumerated from 1 to 7 are recommended for use in cold conditions, while ensembles for summer months are numerated with 8 to 12 , Table 1 .

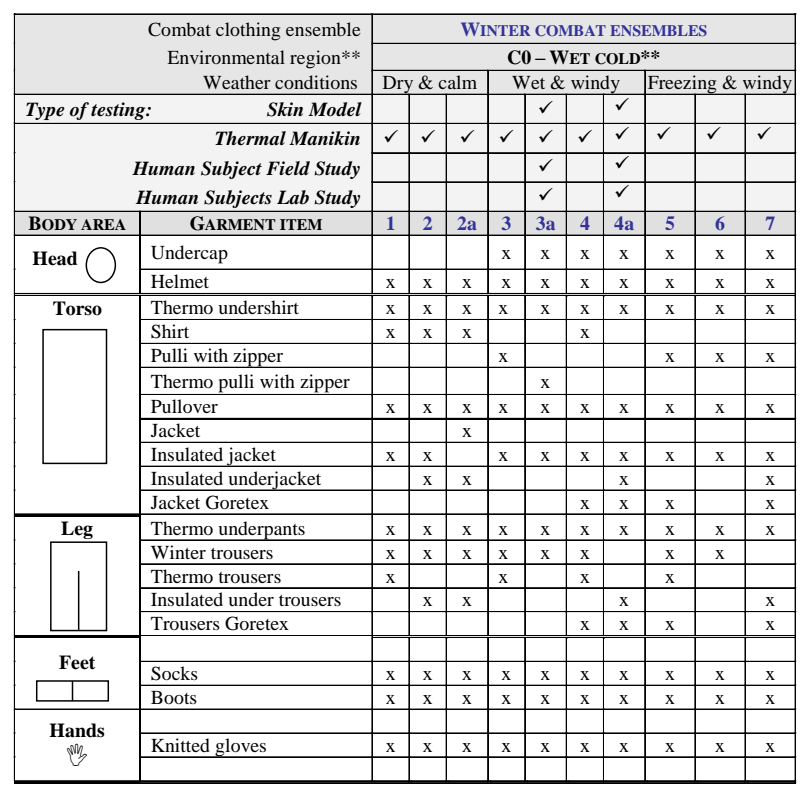

Tab.1. Garment items of winter combat ensembles

\begin{tabular}{|c|c|c|c|c|c|c|}
\hline \multirow{3}{*}{\multicolumn{2}{|c|}{$\begin{array}{r}\text { Combat clothing ensemble } \\
\text { Environmental region** } \\
\text { Weather conditions }\end{array}$}} & \multicolumn{5}{|c|}{ SUMMER COMBAT ENSEMBLES } \\
\hline & & \multicolumn{4}{|c|}{ B2 - WET AND HOT** } & \multirow{2}{*}{$\begin{array}{l}\text { A1- } \\
\text { EXTREMELY } \\
\text { HOT AND } \\
\text { DRY** }\end{array}$} \\
\hline & & \multicolumn{2}{|c|}{$\begin{array}{l}\text { Dry \& } \\
\text { calm }\end{array}$} & \multicolumn{2}{|c|}{ Wet \& windy } & \\
\hline \multicolumn{2}{|c|}{$\begin{array}{lr}\text { Type of testing: } & \begin{array}{r}\text { Skin } \\
\text { Model }\end{array} \\
\end{array}$} & & & & $\checkmark$ & \\
\hline \multirow{3}{*}{\multicolumn{2}{|c|}{$\begin{array}{r}\text { Thermal Manikin } \\
\text { Subject Field Study } \\
\text { Subjects Lab Study }\end{array}$}} & $\checkmark$ & $\checkmark$ & $\checkmark$ & $\checkmark$ & $\checkmark$ \\
\hline & & & & & $\checkmark$ & \\
\hline & & & & & & $\checkmark$ \\
\hline BODY AREA & GARMENT ITEM & 8 & 9 & 10 & 11 & 12 \\
\hline \multirow[t]{2}{*}{ Head } & Undercap & & & & & \\
\hline & Helmet & $\mathrm{X}$ & $\mathrm{X}$ & $\mathrm{X}$ & $\mathrm{X}$ & $\mathrm{X}$ \\
\hline \multirow[t]{5}{*}{ Torso } & Undershirt 50 & & & $\mathrm{X}$ & $\mathrm{X}$ & \\
\hline & Undershirt 28 & $\mathrm{X}$ & $\mathrm{X}$ & & & \\
\hline & Shirt (prototype) & & & & & $\mathrm{X}$ \\
\hline & Overshirt & $\mathrm{X}$ & $x$ & $x$ & $x$ & \\
\hline & \begin{tabular}{|l|} 
Anorak Goretex \\
\end{tabular} & & $\mathrm{X}$ & & $\mathrm{X}$ & \\
\hline \multirow[t]{5}{*}{ Leg } & Underpants 50 & & & $\mathrm{X}$ & $\mathrm{X}$ & $\mathrm{X}$ \\
\hline & \begin{tabular}{|l} 
Underpants 28 \\
\end{tabular} & $\mathrm{X}$ & $\mathrm{X}$ & & & \\
\hline & \begin{tabular}{|l|} 
Summer trousers 1 \\
\end{tabular} & $\mathrm{X}$ & $\mathrm{X}$ & $\mathrm{X}$ & $\mathrm{X}$ & \\
\hline & \begin{tabular}{|l|} 
Prototype trousers \\
\end{tabular} & & & & & $\mathrm{X}$ \\
\hline & \begin{tabular}{|l|} 
Trousers Goretex \\
\end{tabular} & & $\mathrm{X}$ & & $\mathrm{X}$ & \\
\hline \multirow[t]{2}{*}{ LegFeet } & Desert socks & $\mathrm{X}$ & $\mathrm{X}$ & $\mathrm{X}$ & $\mathrm{X}$ & $\mathrm{X}$ \\
\hline & Desert boots & $\mathrm{X}$ & $x$ & $x$ & $\mathrm{X}$ & $\mathrm{X}$ \\
\hline & & & & & & \\
\hline
\end{tabular}

Tab.2. Garment items of summer combat ensembles

Garment thermal resistances were measured using a manikin, as described previously. Resistance, $\mathrm{RT}_{\mathrm{i}}$, expressed in "clo" was computed using Eqn. 1, values are shown in Table 3.

As a consequence of the thermal manikin tests, and the field trials with human subjects, we were able to determine the optimal combat clothing ensembles for summer and winter hikes, and for guard duty in winter months. For cold environments the optimal combat clothing ensemble for hiking was ensemble $3 \mathrm{a}$, while for guard duty ensemble 4a was considered optimal. For summer hikes clothing ensemble 8 was deemed optimal.

\begin{tabular}{|c|c|c|c|c|c|c|}
\hline $\begin{array}{c}\text { Combat } \\
\text { clothing } \\
\text { ensembles }\end{array}$ & Arms & Legs & $\begin{array}{c}\text { Torso } \\
\text { front }\end{array}$ & $\begin{array}{c}\text { Torso } \\
\text { back }\end{array}$ & \multicolumn{2}{|c|}{ Overall } \\
\cline { 2 - 7 } & {$[$ clo] } & {$[$ clo] } & {$[$ clo] } & [clo] & \multicolumn{2}{|c|}{$\left[\right.$ clo] $\left[\mathrm{m}^{2} \mathrm{~K} / \mathrm{W}\right]$} \\
\hline 1 & 2,73 & 2,51 & 4,44 & 2.54 & 3,06 & 0,46 \\
\hline 2 & 3,72 & 3,69 & 3,66 & 4,03 & 3,77 & 0,56 \\
\hline $2 \mathrm{a}$ & 2,69 & 3,71 & 3,15 & 3,86 & 3,35 & 0,5 \\
\hline 3 & 2,69 & 2,81 & 3,06 & 2,47 & 2,76 & 0,41 \\
\hline $3 \mathrm{a}$ & 3,08 & 1,92 & 2,52 & 2,47 & 2,5 & 0,38 \\
\hline 4 & 2,54 & 3,04 & 4,87 & 2,73 & 3,29 & 0,49 \\
\hline $4 \mathrm{a}$ & 3,03 & 3,94 & 4,37 & 4,6 & 3,98 & 0,60 \\
\hline 5 & 2,95 & 3,47 & 3,69 & 2,59 & 3,17 & 0,48 \\
\hline 6 & 3,04 & 1,44 & 2,75 & 2,31 & 2,27 & 0,36 \\
\hline 7 & 2,91 & 3,30 & 3,76 & 4,24 & 3,55 & 0,53 \\
\hline 8 & 1,21 & 1,83 & 1,25 & 1,39 & 1,42 & 0,21 \\
\hline 9 & 2,28 & 2,66 & 2,43 & 1,55 & 2,23 & 0,34 \\
\hline 10 & 1,08 & 2,18 & 1,63 & 1,23 & 1,53 & 0,23 \\
\hline 11 & 2,35 & 2,86 & 2,12 & 1,95 & 2,32 & 0,35 \\
\hline 12 & 1,97 & 2,04 & 1,9 & 1,32 & 1,56 & 0,27 \\
\hline
\end{tabular}

Tab. 1. Clothing thermal resistances expressed in clo values

\section{CONCLUSION}

Protective combat clothing ensembles must be carefully designed to allow heat transfer from a wearer to the environment at an appropriate rate during various work intensities over a range of environmental conditions. Based on the obtained results using a thermal manikin and those obtained with human subjects during summer and winter field trials, we have defined optimal clothing ensembles for cold and mild warm environments.

\section{ACKNOWLEDGEMENTS}

This study was supported, in part, by a Knowledge for Security and Peace grant from the Ministries of Defence, and of Science of the Republic of Slovenia.

\section{REFERENCES}

Goldman R.F., Kampmann B. (2007): Handbook on clothing; Biomedical Effects of Military Clothing and Equipment Systems, $2^{\text {nd }}$ Edition, NATO Research Study Group 7 on Bio-medical Research Aspects of Military Protective Clothing

Havenith G. \& Nilsson O.H. (2004): Correction of clothing insulation for movement and wind - a meta-analysis, Eur J Appl Physiology; 92: pp.636-640

Mekjavic I.B. et al. (2005): Foot temperatures and toe blood flow during a $12 \mathrm{~km}$ winter hike and guard duty. RTOMP-HFM-126, RTO/NATO, pp.1-4

Qian, X. \& Fan J. (2006): Prediction of Clothing Thermal Insulation and Moisture Vapour Resistance of the Clothed Body Walking in Wind. Ann. Occup. Hyg., Vol. 50, No. 8, pp. 833-842

Umbach K.H. (1987): Physiological tests and evaluation models for the optimisation of the performance of protective clothing. In: Env. Erg. Sustaining Human Performance in Harsh Env.Philadelphia, pp. 139-161

Zavec Pavlinic D. \& Mekjavic I.B. (2009): Potrebe okolja sooblikujejo specifične bojne oblačilne sisteme, Slovenska vojska, No. 16, pp. 29 - 31.(in Slovene) 